\title{
Flavonoid isolation and identification of mother-in-law's tongue leaves (sansevieria trifasciata) and the inhibitory activities to xanthine oxidase enzyme
}

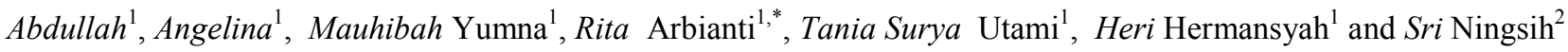 \\ ${ }^{, 1}$ Department of Chemical Engineering, Faculty of Engineering, Universitas Indonesia, Depok 16424, Indonesia \\ ${ }^{2}$ Center for Medical and Pharmaceutical Technology, Badan Pengkajian dan Penerapan Teknologi, Serpong, Indonesia
}

\begin{abstract}
Hyperuricemia is a disease that is characterized by high uric acid levels, in which the number of victim increase year by year in the worldwide. Flavonoid is an active compound with inhibitory activity towards Xanthine Oxidase Enzyme which is a compound that plays a role in the formation of uric acid in the body. Sansevieria trifasciata is an ornamental plant which is also useful as a source of antibacterial and antioxidant agent. Studies of S. trifasciata as Xanthine Oxidase Enzyme inhibitor have not been reported. This research isolate flavonoid compounds using open column chromatography from crude extract of $S$. trifasciata leaves that extracted by sonication method. There are six eluent used to isolate flavonoid which are methanol : ethyl acetate, chloroform : ethyl acetate, chloroform : ethyl acetate :methanol. Wilstater test is used to select the fraction that rich of flavonoid. The best result from isolation step that contains flavonoid is assessed the inhibitory activity of xanthine oxidase. It is analyzed qualitative using Liquid Chromatography Mass Spectrometry (LCMS). The inhibition percentage showed that fraction 3 was potential to inhibit XO by $85.48 \%$. LC-MS chromatogram can show that crude extract and positive fraction of isolation were containing falvonoid.
\end{abstract}

\section{Introduction}

Hyperuricemia, associated with gout, results from the overproduction or underexcretion of uric acid and it is greatly influenced by a high dietary intake of foods rich in nucleic acids. The traditional diets of Indonesia were especially high in wild meat, which could be expected to contribute to gout, meats (especially organ meats), leguminous seed, some types of seafood and food yeasts that are considered rich of nucleic acids [1]. The catalysis of xanthine by the enzyme xanthine oxidase (XO) (EC 1.2.3.2) can lead to the accumulation of uric acid and ultimately causing gout. Joint disease that occurs due to accumulation of uric acid crystals was in top five diseases with the highest prevalence in Indonesia spread in 33 provinces with prevalence reached $24.7 \%$. Allopurinol is an XO inhibitor prescribed for chronic gout, acts as a competitive inhibitor of the enzyme. However, allopurinol has side effects for the body. The most feared side effect of Allopurinol is the so-called "allopurinol hypersensitivity syndrome". Signs and symptoms of this syndrome are wound, high fever (usually $>39^{\circ} \mathrm{C}$ ), liver dysfunction, leukocytosis, and renal failure [2]. Many plants are used by Indigenous people for the treatment of gout, or diseases with associated symptomologies such as rheumatism or arthritis, and we postulate that these may

contain XO inhibitors. XO inhibitors have been found in a wide variety of plants used in traditional herbal medicines for the treatment of gout and rheumatism for example Chile [3] Paraguay [4] [5] [6] and Panama [7].

Flavonoids [8][9], and certain other phenols ${ }^{[10]}$, polyphenols [10] and tannins [10], as well as coumarins [11], plant growth regulators [12] and folic compounds [13] have all been reported to be potent XO inhibitors. The putative therapeutic effects of many traditional medicines have been ascribed to flavonoids in particular due to their enzyme inhibitory and antioxidant activity [14] [15].

In particular Sansevieria trifasciata which in South Africa and tropical America is used for the treatment of inflammatory conditions and sold as a crude drug in the market to treat victims of snake bite [16]. It is also used for the treatment of ear pain, swellings, boils and fever [17]. Previous chemical studies on Sansevieria trifasciata led to the isolation of flavonoid [18] steroidal sapogenins namely 25S-ruscogenin and sansevierigenin [19] ,pregnane glycosides [20], and steroidal saponins [21]. Therefore, we expect a positive correlation between XO inhibitory activity and flavonoid content of plant extracts.

Corresponding author: arbianti@che.ui.ac.id 
The objective of this study is to know the effect of eluent polarity index from six eluent methanol:ethyl acetate $(4: 1)$, chloroform:ethyl acetate $(1: 6,9: 1$ and $1: 2)$, chloroform:ethyl acetate:methanol $(1: 2: 1$ and $1: 2: 2)$ with the separation result and to determine the validity of

\section{Materials and Methodology}

\subsection{Materials}

\subsubsection{Substances}

The dried leaves of Sansevieria trifasciata were obtained from Bogor, Indonesia. methanol, chloroform, hydrochloric acid, natrium hydroxide, ethanol, ethyl acetate and mg powder (merck) were obtained from bioprocess engineering laboratory. The Xanthin (X0626) and xanthin oxidase (Sigma X4375) were obtained from Badan Pengkajian dan Penerapan Teknologi (BPPT).

\subsubsection{Instruments}

Ultrasonic cleaner bath, Spectrophotometer UV-VIS (BEL Engineering UV-M90), Liquid Chromatography and Mass Spectrometry (LC-MS)

\subsection{Methodology}

\subsubsection{Preparation leaf of Mother in-law tongue simplicia}

$1000 \mathrm{~g}$ wet weight of mother in-law's tongue leaves were sorted washed, and drained by using the oven at $60^{\circ} \mathrm{C}$ for $8 \mathrm{~h} /$ day and the sample was smoothed with a blender and sieve analyzer to obtain the sample powder diameter $\pm 0.15-0.18 \mathrm{~mm}$.

\subsubsection{Extraction Method}

Mother-in-law's tongue leaves powder was dissolved in $70 \%$ ethanol by $1: 10$ ratio of mass and solvent $(\mathrm{m} / \mathrm{v})$. Then, extraction using sonicator for 60 minutes at frequency of $53 \mathrm{kHz}$ and $27^{\circ} \mathrm{C}$, continued by solvent evaporating using vacuum rotary evaporator.

\subsubsection{Best eluent determination}

The Best eluent was determined with Thin Layer chromatography (TLC) silica $\mathrm{G} 60 \mathrm{~F}_{254}$ using different eluent that used to isolate flavonoid which are methanol:ethyl acetate (4:1), chloroform:ethyl acetate (1:6, 9:1 and 1:2), chloroform:ethyl acetate:methanol $(1: 2: 1$ and $1: 2: 2)$. The eluent that have rf number closer to standard which is quercetin and give the best separation will be used in isolation method as mobile phase.

\subsubsection{Isolation Methode}

plant remedies used for gout by examining their xanthine oxidase inhibitory activity and whether a relationship exists between enzyme inhibition and the flavonoid and other content.

The isolation using column chromatography method using silica Gel 60 as stationary phase, aims to separate the compounds in a crude extract into some fractions using the best eluent for mobile phase determined in the previous experiment and the same rf number of many fraction will be put together.

\subsubsection{Wilstater test}

In every fraction of samples were added 2-4 drops of concentrated $\mathrm{HCl}$ and a pinch of $\mathrm{Mg}$ powder. Then observe the color change occurs, it should turns into a reddish orange color [22].

\subsubsection{Xanthine Oxidase Inhibition Test}

The XO activities with xanthine as the substrate were measured spectrophotometrically using the procedure of Marcocci et al. (1994) [23] with the following modifications. The xanthine solution $(0.15 \mathrm{mM})$ was prepared by initially dissolving xanthine (Sigma) in a minimal volume of $\mathrm{NaOH}$, and adjusting $\mathrm{pH}$ to 7.5. The $\mathrm{XO}$ solution was pre pared by diluting $\mathrm{XO}$ from bovine's milk (Sigma) to a final concentration of $0.1 \mathrm{U} / \mathrm{ml}$ in cold $50 \mathrm{mM}$ potassium phosphate buffer $(\mathrm{pH} 7.5)$. The assay mixture consisted of $0.250 \mathrm{ml}$ plant extract solution $(0.4$ $\mathrm{mg}: \mathrm{ml} 50 \mathrm{mM}$ potassium phosphate buffer, $\mathrm{pH} 7.5$ ), $0.385 \mathrm{ml} 50 \mathrm{mM}$ potassium phosphate buffer $(\mathrm{pH} \mathrm{7.5)}$ and $0.330 \mathrm{ml}$ xanthine solution, giving a final concentration of $100 \mathrm{mg}$ plant extract per ml assay mixture. The reaction was initiated by adding $0.035 \mathrm{ml}$ $\mathrm{XO}$ solution, and the change in absorbance recorded at $295 \mathrm{~nm}$ for $3 \mathrm{~min}$ at room temperature. Allopurinol (Sigma) was used as a standard inhibitor at a final concentration of $100 \mathrm{mg} / \mathrm{ml}$ in the assay mixture [24].

\subsubsection{Quantitative test using LC-MS}

Quantitative test is used to analyze the concentration of compounds in crude extract and isolate fractions by using LC-MS method.

\section{Result and Discussion}

\subsection{Yield percentage value of Mother-in-Law's Tongue extract}

The extract of leaf was done by sonication method at $37^{\circ} \mathrm{C}$ for 50 minutes. From this extraction results obtained viscous extract of 4.53 grams of 25 grams simplicia. Based on the calculation, the extraction yield is 18.12 percent. This method give more yield precentage if we compare to another study of Sansevieria trifasciata extraction using maseration and methanol as the solvent nurlaila 2011 that have 15.5 
yield percentage [25]. In the sonication method, cavitation occurs when the ultrasonic wave treatment is done to break down the cell wall of the simplicia material. Cavitation is the process of forming micro bubbles (microbubbles) due to increased pressure at the time of extraction as a result of ultrasonic waves. The bubbles are so unstable that they break easily when the bubbles reach an insufficient volume to absorb energy. The breaking of the bubbles involves a large amount of energy and produces a heat effect that helps contact between the solvent and the material in the extraction so that the extraction results are maximal. The mechanical effect of the sonication method is to increase the penetration of the solvent into the material cell and increase the mass transfer so that the time required for cell splitting is not too long [26].

\subsection{Best eluent determination}

The Thin Layer Chromatography Method in this study was used to find the best eluent of some of the eluents present in the separation of flavonoid compounds. The concentrated extract should be diluted first with a small amount of methanol and filtered using filter paper. It aims to make the elution process work well. If the extract is too thick it will be difficult to get carried away by the solvent. The mobile phase or eluent used in the study consisted of 6 types of eluent: methanol:ethyl acetate (4:1), chloroform:ethyl acetate (1:6, 9:1 and $1: 2)$, chloroform:ethyl acetate:methanol (1:2:1 and 1:2:2). The following is the stain sighting data from the crude extract elution using TLC, viewed using 366nm ultraviolet lamp.

Table 1. Crude extract TLC data result using some eluents

\begin{tabular}{cccc}
\hline Eluent & Mark & Tailed & $\begin{array}{c}\text { Well } \\
\text { Separated }\end{array}$ \\
\hline $\begin{array}{c}\text { Methanol:Ethyl } \\
\text { Acetate }(4: 1)\end{array}$ & 3 & - & $\sqrt{ }$ \\
\hline $\begin{array}{c}\text { Chloroform:Ethyl } \\
\text { Acetate (1:6) }\end{array}$ & 1 & - & - \\
\hline $\begin{array}{c}\text { Chloroform:Ethyl } \\
\text { Acetate (9:1) }\end{array}$ & 1 & - & - \\
\hline $\begin{array}{c}\text { Chloroform:Ethyl } \\
\text { Acetate (1:2) }\end{array}$ & 2 & - & - \\
\hline $\begin{array}{c}\text { Chloroform:Ethyl } \\
\text { Acetate:Methanol } \\
\text { (1:2:1) }\end{array}$ & 1 & - & - \\
\hline $\begin{array}{c}\text { Chloroform:Ethyl } \\
\text { Acetate:Methanol } \\
(1: 2: 1)\end{array}$ & 2 & - & - \\
\hline
\end{tabular}

In Table 1 shows the number of stains and profile of the stain formed, which is a parameter to see if the eluent provides good separation. The best eluent is the one that produces the highest number of stains and forms a clear or non-tailed spot on the plate this is due to the different distribution of the compounds present in the simplicia based on their polarity, when the eluent used is a polar eluent according to the compounds contained in the extract [27]. which is in this study methanol and ethyl asetate $(4: 1)$ was the best eluent to separate the sample.
Isolation of flavonoids is affected by the polarity of the solvent, where the polarity of a solution is related to the polarity index and if the polarity index value increases then the polarity of a solvent also increases. Based on the calculation of polarity index in every eluent, methanol and ethyl asetate $(4: 1)$ has the higher number of polarity index.

\subsection{Isolation and qualitative test result}

The chromatography column used is the chromatography column of silica gel. The columns are prepared by the wet method ie the method by which the silica gel incorporated into the chromatographic column has the form of a silica slurry. Wet method is chosen because silica gel is easy to mix (homogeneous). Eluen used was a mixture of methanol and ethyl acetate with a ratio of 4 : 1. The crude extract is placed in the column and will be absorbed into the silica gel stationary phase before eluting with methanol and ethyl acetate. When elution takes place, the color of the crude extract then gradually becomes faded. This shows that there is a reaction between the extract and the stationary phase. After that happened yellow separation and gradually the colors of the separation become lost. The column chromatographic fractions were divided into 27 fractions which were further tested using thin layer chromatography to determine simillar Rf number, so it becomes 7 fractions.

Wilstater test was conducted to the 7 fractions obtained to confirm the presence of flavonoid compounds.

Table 2. Results of Wilstater test.

\begin{tabular}{cc}
\hline Number of Fraction & Flavonoid \\
\hline 1 & - \\
\hline 2 & - \\
\hline 3 & + \\
\hline 4 & + \\
\hline 5 & - \\
\hline 6 & - \\
\hline 7 & - \\
\hline
\end{tabular}

Based on the data obtained fractions 3 and 4 contain flavonoids, which at the time of the test made a change of color from yellowish orange to reddish orange. the purpose of addition of concentrated $\mathrm{HCl}$ and $\mathrm{Mg}$ powder in this test is to reduce benzopiron contained in the flavonoid structure so that the color changes to orange or red. After the addition of $\mathrm{Mg}$ powder, the sample was heated and added $\mathrm{HCl}$. $\mathrm{HCl}$ testing resulted in the result that the sample changed color to orange. This indicates a reduction oxidation reaction between $\mathrm{Mg}$ powder as a reducer, with a flavonoid sample. The oxidation reaction of reduction between $\mathrm{Mg}$ powder and flavonoids, causing the formation of complex compounds that give rise to orange in the sample.

\subsection{Xanthine Oxidase Inhibition Test}


Xanthine oxidase activity was expressed as percent inhibition of xanthine oxidase, calculated as (1$\mathrm{B} / \mathrm{A}) \mathrm{x} 100$, where $\mathrm{A}$ is the change in absorbance of the assay without the plant extract ( $\Delta$ abs. with enzyme $\Delta$ abs. without enzyme), and $\mathrm{B}$ is the change in absorbance of the assay with the plant extract ( $\Delta$ abs. with enzyme - $\Delta$ abs. without enzyme) [24].

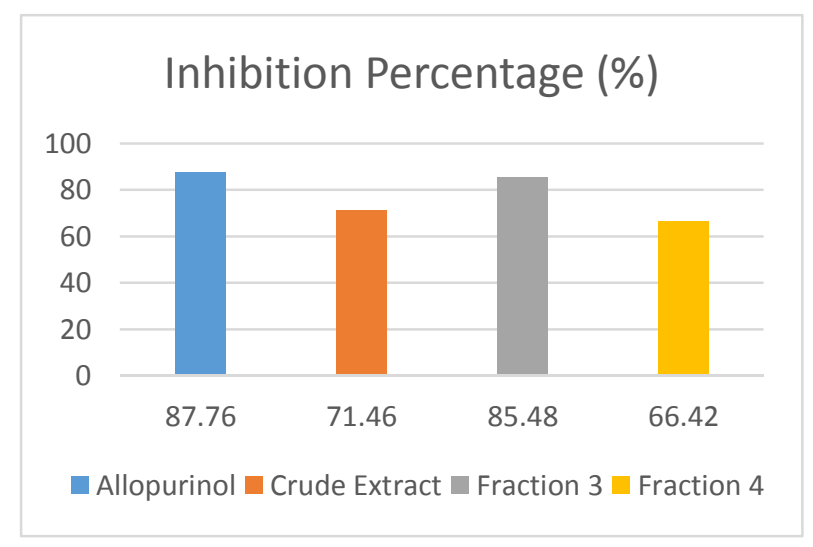

Fig 1. Results of XOI.

Figure 1 shows the results of xanthine oxidase inhibition test. Fraction 3 has the biggest inhibition percentage compared to crude extract and faction 4 . Allopurinol is a compound that has the greatest inhibitory value in inhibiting uric acid formation, since allopurinol is a competitive reversible inhibitor, a competitive inhibitor has a structure similar to that of the substrate, causing competition between the substrate and the inhibitor in binding the active side of the enzyme [28].

Kinetical analysis that shown by Lineweaver-Burk ${ }^{[24]}$ suggests that this type of inhibition was inhibitors with competitive inhibitory mechanisms are compounds that have structures resembling substrate structures [29] and flavonoid compounds have similar structures with xanthin substrates [27].

\subsection{Quantitative test using LC-MS}

The LC-MS analysis was performed on crude extract, fraction 3 and fraction 4 (Fig. 2). The results was obtained from LC-MS were chromatographic curves from LC and molecular weight graph from MS for retention time. The results of the tests performed are shown in Table 4.

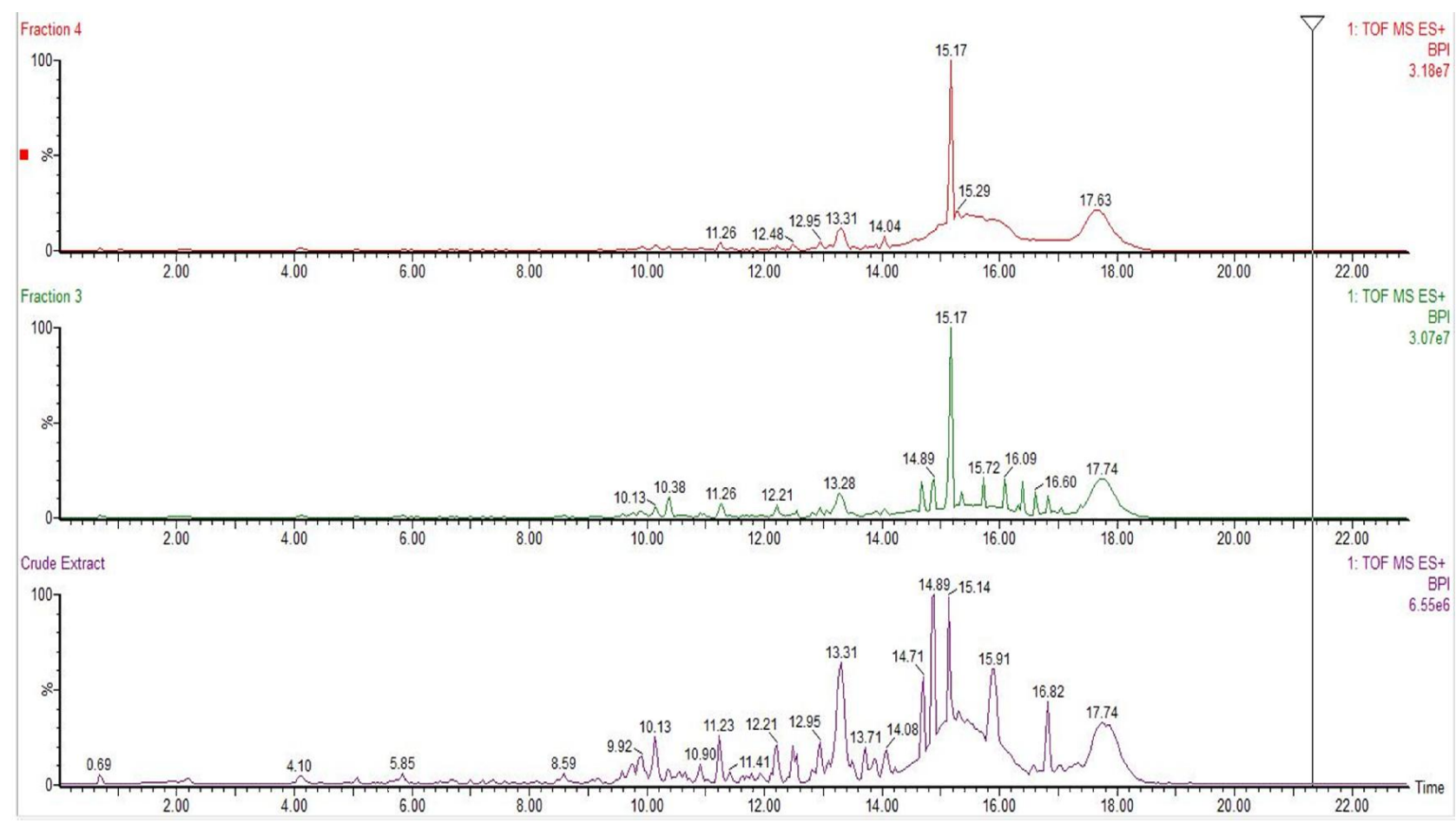

Fig. 2. LC-MS results 
Table 4. LC-MS data result in every sample

\begin{tabular}{ccccc}
\hline Compound & Rt & Chemical Formula & Molecular Weight & Active Compound Content \\
\hline \multirow{4}{*}{ Crude Extract } & 11.23 & $\mathrm{C}_{16} \mathrm{H}_{15} \mathrm{O}_{5}$ & 287.28 & Flavonoid (flavonones ) \\
\cline { 2 - 5 } & 12.21 & $\mathrm{C}_{32} \mathrm{H}_{27} \mathrm{O}_{10}$ & 570.54 & Flavonoid (isoflavone) \\
\cline { 2 - 5 } & 14.89 & $\mathrm{C}_{36} \mathrm{H}_{33} \mathrm{~N}_{8} \mathrm{O}_{2}$ & 68.077 & Alkaloid (imidazol) \\
\cline { 2 - 5 } & 15.14 & $\mathrm{C}_{36} \mathrm{H}_{33} \mathrm{~N}_{8} \mathrm{O}$ & 592.696 & Pheophorbide A, \\
\cline { 2 - 5 } & 0.69 & $\mathrm{H}_{3} \mathrm{O}_{14}$ & 146.143 & Polyphenol (coumarins) \\
\cline { 2 - 5 } & 12.95 & $\mathrm{C}_{9} \mathrm{H}_{7} \mathrm{O}_{3}$ & 162.14 & Polyphenol (hydrocoumarins) \\
\hline \multirow{3}{*}{ Fraction 3 } & 8.59 & $\mathrm{C}_{44} \mathrm{H}_{69} \mathrm{O}_{17}$ & 870 & Saponin \\
\cline { 2 - 5 } & 11.26 & $\mathrm{C}_{16} \mathrm{H}_{15} \mathrm{O}_{5}$ & 287.28 & Flavonoid (flavonones) \\
\cline { 2 - 5 } & 14.89 & $\mathrm{C}_{36} \mathrm{H}_{33} \mathrm{~N}_{8} \mathrm{O}_{2}$ & 68.077 & Alkaloid (imidazol) \\
\hline \multirow{2}{*}{ Fraction 4 } & 15.17 & $\mathrm{C}_{36} \mathrm{H}_{33} \mathrm{~N}_{8} \mathrm{O}$ & 592.696 & Pheophorbide A, \\
& 11.26 & $\mathrm{C}_{16} \mathrm{H}_{15} \mathrm{O}_{5}$ & 287.28 & Flavonoid (flavonones) \\
\cline { 2 - 4 } & 15.17 & $\mathrm{C}_{36} \mathrm{H}_{33} \mathrm{~N}_{8} \mathrm{O}$ & 592.696 & Pheophorbide A, \\
\hline
\end{tabular}

Based on these results the cooperation between flavonoid compounds, alkaloids, and pheophorbide A which are not disturbed by polyphenol compounds work better it when compared with crude extract or isolation in XOI precentage results. Although it has been said that flavonoid and polyphenol compounds may act as xanthine oxidase inhibitors ${ }^{[8]}[9]{ }^{[10]}$, the results of this study show that the performance of the active compounds will be different when they separate.

\section{Conclusion}

The extraction result using sonication method was obtained 18,12\% of yield. Methanol: Ethyl Acetate (4: 1) is a better eluent to separate the sample and from the isolation result by using column chromatography was obtained 7 main fractions and based on wilstater test fractions 3 and 4 containing flavonoid compound.

Based on the inhibition test of xanthine oxidase activity, it was found that the largest percentage of inhibition was performed by the third fraction with $85.48 \%$ followed by crude extract and the fourth fraction respectively $71.46 \%$ and $66.42 \%$.

Based on the results of LC-MS indicated the success of the isolation process due to the survival of flavonoid compounds and the disappearance of some components in each fraction there.

The authors wish to thank Universitas Indonesia via Grant of International Publication Indexed for Thesis of UI's Students or known as PITTA 2018 .

\section{References}

1. Sarwar, G., And Brule', D Assessment of the uricogenic potential of processed foods based on the nature and quantity of dietary purines. Progress in Food and Nutrition Science 15(1), pp.159-181 (1991)

2. Hardman J.G. and Limbird, L.E. (Eds.). Goodman and Gilman's The Pharmacological Basis of Therapeutics (9th ed.). (1975)

3. Theoduloz, C., Pacheco, P., Schmeda-Hirschmann, G Xanthine oxidase inhibitory activity of Chilean Myrtaceae. Journal of Ethnopharmacology 33(1), pp. 253-255 (1991)

4. Hayashi, T., Nagayama, K., Arisawa, M., Shimizu, M., Suzuki, S., Yoshizaki, M.and, Morita, N Pentagalloyglucose, a xanthine oxidase inhibitor from Paraguayan crude drug, 'Molle-I' (Schinus terebinthifolius). Journal of Ethnopharmacology 52(1), pp.210-211 (1989)

5. Schmeda-Hirschmann, G., Theoduloz, C., Franco, L., Ferro, E., Rojas de Arias, A Preliminary pharmacological studies on Eugenia uniflora leaves: xanthine oxidase inhibitory activity. Journal of Ethnopharmacology 21(1), pp. 183-186 (1987)

6. Theoduloz, C., Franco, L., Ferro, E., SchmedaHirschmann, G Xanthine oxidase inhibitory activity of Paraguayan Myrtaceae. Journal of Ethnopharmacology 24(1), pp. 179-183 (1988)

7. Gonza'lez, A.G., Bazzocchi, I.L., Moujir, L., Ravelo, A.G., Correa, M.D., Gupta, M.P Xanthine oxidase inhibitors of some Panamanian plants from Celastraceae and Lamiaceae. Journal of Ethnopharmacology 46(1), pp. 25-29 (1995) 
8. Iio, M., Moriyama, A., Matsumoto, Y., Takaki, N., Fukumoto, M Inhibition of xanthine osidase by flavonoids by folate compounds and amethopterin. Journal of Biological Chemistry 259(1), pp. 12-15 (1985)

9. Chang, W.S., Lee, Y.J., Lu, F.J., Chiang, H.C Inhibitory effects of flavonoids on xanthine oxidase. Anticancer Research 13(1), pp.2165-2170 (1993)

10. Hatano, T., Yashuhara, T., Fukuda, T., Noro, T., Okuda, TPhenolic constituents of licorice II. Structures of licopyranocoumarin, licoarylcoumarin and glisoflavone, and inhibitory effects of licorice phenolics on xanthine oxidase. Chemical and Pharmaceutical Bulletin 37 (1), pp.3005-3009 (1989)

11. Chiang, H.C, Juilo, Y., Lu, F.J., 1994. Xanthine oxidase inhibitors from the leaves of Alsophila spinulosa (Hook) Tryon. Journal of Enzyme Inhibition 81(1), pp.61-71 (1994)

12. Sheu, S.Y., Chiang, H.C Inhibitory effects of plant growth regulators on xanthine oxidase. Anticancer Research 16(1), pp.311-316 (1996)

13. Lewis, A.S., Murphy, L., McCalla, C., Fleary, M., Purcell, S Inhibition of mammalian xanthine oxidase by folate compounds and amethopterin. Journal of Biological Chemistry 259(1), pp.12-15 (1984)

14. Havsteen, B Flavonoids, a class of natural products of high pharmacological potency. Biochemical Pharmacology 32(1), pp.1141-1148 (1983)

15. Brandi, M.LFlavonoids: biochemical effects and therapeutic applications. Bone and Mineral 19(1), pp.S3-S14 (1992)

16. Antunes, A.D.S., Da Silva, B.P., Parente, J.P., Valente, A.PA new bioactive steroidal saponin from Sansevieria cylindrica. Phytother. Res. 17(1), pp.179-182 (2003)

17. Anbu, J.S.J., Jayaraj, P., Varatharajan, R., John, T., Jisha, J., Muthappan, M Analgesic and antipyretic effects of Sansevieria trifasciata leaves. Afr. J. Trad. CAM 6(1), pp.529-533 (2009)

18. Tchegnitegni B.T Sappanin-type homoisoflavonoids from Sansevieria trifasciata Prain Phytochemistry Letters 12 (1), pp. 262-266 (2015)

19. Gonzalez, A.G., Freire, R., Garcia-Estrada, M.G., Salazar, J.A., Suarez, E New sources of steroid sapogenins - XIV. 25S-Ruscogenin and sansevierigenin: two new spirostane sapogenins from Sansevieria trifasciata. Tetrahedron 28(1), pp.12891297 (1972)

20. Mimaki, Y., Inoue, T., Kuroda, M., Sashida, Y Pregnane glycosides from Sansevieria trifasciata. Phytochemistry 44(1), pp.107-111 (1997)

21. Mimaki, Y., Inoue, T., Kuroda, M., Sashida, YSteroidal saponins from Sansevieria trifasciata. Phytochemistry 43(1), pp.1325-1331 (1996)

22. Achmad., S.A Kimia Organik Bahan Alam, Kamunika, Jakarta (1986)

23. Marcocci, L., Packer, L., Droy-Lefaix, M.T., Sekaki, A., Garde`s-Albert, M Antioxidant action of Ginko biloba extract Egb 761. Methods in Enzymology 234(1), pp.462-476 (1994)

24. Owen P. L, Jhons T., J. Ethnopharmacol., 64, pp.149-160 (1999).
25. Nurlaila Fraksi Aktif Ekstrak Daun Sansevieria trifasciata Prain Sebagai Penghambat Pertumbuhan Sel Lestari HeLa. S1. Bogor: IPB (2011)

26. Xu, DP, Zheng, J., Zhou, Y., Li, Y., Li, S. and Li, HB, Ultrasound-assisted Extraction of Natural Antioxidants from the Flower of Limonium sinuatum: Optimization and Comparison with Conventional Methods, Food chemistry, 217, pp.552-559 (2017)

27. Auliawati, Yenni. Ekstraksi Tanin dari Daun Jambu Biji (Psidium guajava) sebagai Inhibitor Enzim Xanthin Oksidase untuk Menurunkan Kadar Asam Urat. [Skripsi]. Depok: Universitas Indonesia (2013)

28. Chaerunissa, A. L. (2013). Ekstraksi Kasar Tanin dari Daun Belimbing Wuluh sebagai Inhibitor Enzim Xantin Oksidase. [Skripsi]. Depok: Universitas Indonesia. (2013)

29. Murray, R. K., Granner, D. K., \& Rodwell, V. W Harper's Illustrated Biochemistry 27th Edition. New York: The McGraw-Hill Companies. (2006) 